\title{
The Activity of Lipid A and Core Components of Bacterial Lipopolysaccharides in the Prevention of the Hypersensitive Response in Pepper
}

\author{
Mari-Anne Newman, Michael J. Daniels, and J. Maxwell Dow \\ The Sainsbury Laboratory, John Innes Centre, Norwich Research Park, Colney Lane, Norwich NR4 7UH, U.K. \\ Received 28 April 1997. Accepted 16 June 1997.
}

\begin{abstract}
Pre-treatment of leaves of pepper (Capsicum annuum) with lipopolysaccharide (LPS) preparations from enteric bacteria and Xanthomonas campestris could prevent the hypersensitive response caused by an avirulent $X$. campestris strain. By use of a range of deep-rough mutants, the minimal structure in Salmonella LPS responsible for the elicitation of this effect was determined to be lipid $A$ attached to a disaccharide of 2-keto-3-deoxyoctulosonate; lipid $A$ alone and the free core oligosaccharide from a Salmonella Ra mutant were not effective. For Xanthomonas, the core oligosaccharide alone had activity although lipid A was not effective. The results suggest that pepper cells can recognize different structures within bacterial LPS to trigger alterations in plant response to avirulent pathogens.
\end{abstract}

The recognition by plants of extracellular or cell surface components of phytopathogenic bacteria has a fundamental role in the interaction of these bacteria with plants. We are particularly interested in responses of plants to bacterial lipopolysaccharides (LPS) and the role that such responses may play in plantmicrobe interactions. It has been known for a number of years that inoculation of tobacco plants with LPS or LPS-protein complexes from a number of bacteria can prevent the hypersensitive response (HR) caused by avirulent plant-pathogenic bacteria. This response, which is light-independent and usually localized to the site of inoculation, requires several hours to become established, suggesting that the protective mechanism depends upon a plant response to LPS. The phenomenon has been interpreted in terms of an LPS-induced resistance response and termed localized induced resistance (reviewed by Sequeira 1983). In contrast, other workers have suggested that LPS induces an increased tolerance of plants to bacteria by mediating a suppression of the HR (Mazzucchi et al. 1979). Although the molecular basis remains obscure, the prevention of HR provides a ready assay of the ability of different LPS forms and different moieties within LPS to trigger alterations in plant response. In this paper, we refer to this effect as the localized induced response (LIR), as this term has no mechanistic implications. Graham et al. (1977) showed that purified LPS from both rough

Corresponding author: Mari-Anne Newman; Telephone: ++44 1603452 571; Fax: ++ 441603250 024; E-mail: newmanm@ bbsrc.ac.uk and smooth forms of Ralstonia solanacearum and from Escherichia coli induced LIR in tobacco at concentrations as low as $50 \mu \mathrm{g} \mathrm{ml}^{-1}$. Hydrolysis of the core oligosaccharide-lipid A linkage of LPS from $R$. solanacearum or E. coli caused a loss of all biological activity. It was suggested that a conserved lipid Ainner core oligosaccharide structure in the LPS from these different bacteria was responsible for the LIR induction in tobacco. The aim of the work described in this paper was to further define the structures within LPS from both enteric bacteria and the plant pathogen $X$. campestris that are required to induce LIR.

We have primarily studied effects of LPS preparations on the HR response in pepper (Capsicum annuum) ECW 10R induced by the avirulent $X$. campestris pv. campestris strain 8004 (see Table 1). LPS preparations from enteric bacteria were purchased from Sigma Chemical Co. (Poole, U.K.). LPS was prepared from the $X$. campestris strains outlined in Table 1 by the hot phenol method (Carlson et al. 1987) and further purified as described previously (Dow et al. 1995). Inoculation of fully expanded leaves of pepper ECW10R with $X$. campestris pv. campestris strain 8004 at $10^{7} \mathrm{CFU} \mathrm{m}{ }^{-1}$ leads to the confluent cellular collapse of the HR within $24 \mathrm{~h}$. This collapse was prevented by pre-inoculation of pepper with LPS preparations from E. coli, Salmonella minnesota, or X. campestris pv. campestris strain 8004 at $50 \mu \mathrm{g} \mathrm{ml}^{-1}$. In all cases, a period of 10 to $12 \mathrm{~h}$ was required between inoculations to ob-

Table 1. Bacterial strains

\begin{tabular}{lcc}
\hline Bacterium & Relevant characteristic & Reference \\
\hline $\begin{array}{l}\text { Xanthomonas campestris pv. } \\
\text { campestris }\end{array}$ & $\begin{array}{c}\text { Wild type; avirulent on } \\
\text { pepper ECW 10R } \\
8004\end{array}$ & $\begin{array}{c}\text { Daniels et } \\
\text { al. } 1984 \\
\text { Dow et al. } \\
\text { lipopolysaccharide) } \\
1995\end{array}$ \\
$\begin{array}{l}\text { X. campestris } \text { pv. vesicatoria } \\
71-21\end{array}$ & $\begin{array}{c}\text { Wild type; virulent on } \\
\text { pepper ECW 10R }\end{array}$ & $\begin{array}{c}\text { Bonas et al. } \\
1989\end{array}$ \\
$\begin{array}{l}\text { X. campestris } \text { pv. raphani } \\
1946\end{array}$ & $\begin{array}{c}\text { Wild type; avirulent on } \\
\text { pepper ECW 10R }\end{array}$ & NCPPB \\
$\begin{array}{l}\text { X. campestris } \text { pv. armoraciae } \\
1930\end{array}$ & $\begin{array}{c}\text { Wild type; avirulent on } \\
\text { pepper ECW 10R }\end{array}$ & NCPPB \\
\hline
\end{tabular}

${ }^{a}$ National Collection of Plant Pathogenic Bacteria, Harpenden, U.K. 
tain complete prevention of the HR. A standard time of $18 \mathrm{~h}$ was used in all subsequent experiments.

The effect of $X$. campestris LPS was not dependent on the strain or on its interaction with pepper ECW10R. Purified LPS from $X$. campestris pv. vesicatoria strain 71-21 (which is virulent on pepper ECW10R) and $X$. campestris pvs. raphani and armoraciae (which are both avirulent on pepper ECW10R) all prevented the HR induced by $X$. campestris pv. campestris strain 8004 at $50 \mu \mathrm{g} \mathrm{ml}^{-1}$. The structural requirements of Xanthomonas LPS for induction of LIR in pepper were assessed by the use of LPS preparations from the wildtype $X$. campestris pv. campestris strain 8004 , from an LPSdefective mutant derivative, strain 8530 (Table 1), and fractions derived from these preparations by mild acid hydrolysis. On extraction of LPS from $X$. campestris pv. campestris strain 8004 with hot phenol, a fraction of the LPS partitions into the phenol phase (Dow et al. 1995). This phenol-phase LPS carries the O-antigen, while water-phase LPS preparations (which were used in the experiments described above) lack the O-antigen and consist of lipid A attached to core oligosaccharides. X. campestris pv. campestris strain 8530 has a truncated core oligosaccharide with no O-antigen. The effects of these LPS preparations on the induction of LIR are shown in Figure 1A. At $50 \mu \mathrm{g} \mathrm{ml}^{-1}$, all these preparations were effective in preventing HR. However, at concentrations lower than 50 $\mu \mathrm{g} \mathrm{ml}{ }^{-1}$ none of these preparations were effective (data not shown). The lipid A and the core oligosaccharide components of the water-phase LPS from X. campestris pv. campestris strain 8004 were separated by mild acid hydrolysis (1\% acetic acid, $100^{\circ} \mathrm{C}, 3 \mathrm{~h}$ ), which cleaves the bond between the two moieties. The core oligosaccharide induced LIR in pepper leaves at concentrations as low as $5 \mu \mathrm{g} \mathrm{m}^{-1}$ (Fig. 1A). As lipid A is not soluble in water, it was solubilized by complexing to bovine serum albumin (BSA) exactly as described by Matsuura et al. (1983). The lipid A moiety (as a noncovalent conjugate to BSA) was totally ineffective at both 5 and $50 \mu \mathrm{g}$ $\mathrm{ml}^{-1}$ (Fig. 1A). As a control, BSA $\left(1 \mathrm{mg} \mathrm{ml}^{-1}\right)$ was inoculated into leaf and found not to be an inducer of LIR. In addition, $E$. coli LPS suspended in a $1 \mathrm{mg} \mathrm{m}^{-1}$ solution of BSA were still effective in inducing LIR, suggesting that BSA did not prevent the LIR reaction.

In the case of the LPS from enteric bacteria, the availability of a series of LPS variants of $S$. minnesota (Rc to Re mutants) with progressive truncations of the core oligosaccharide allowed identification of the minimal lipid A-core structure responsible for the elicitation of LIR. As shown in Figure 1B, purified LPS from $S$. minnesota $\mathrm{Rc}$ and Rd mutants at $50 \mu \mathrm{g}$ $\mathrm{ml}^{-1}$ completely prevented HR. LPS from the Re mutant, which only contains the lipid A attached to a disaccharide of 2-keto-3-deoxyoctulosonate (KDO), gave partial inhibition. Lipid A alone was ineffective (Fig. 1B). At lower concentrations, LPS from the Salmonella Rc, Rd, or Re mutants did not prevent HR. When used at higher concentration, LPS from the $S$. minnesota Re mutant still gave the partial inhibition seen at $50 \mu \mathrm{g} \mathrm{ml}^{-1}$. The core oligosaccharide derived from LPS from the $S$. minnesota Ra mutant by mild acid hydrolysis was to-
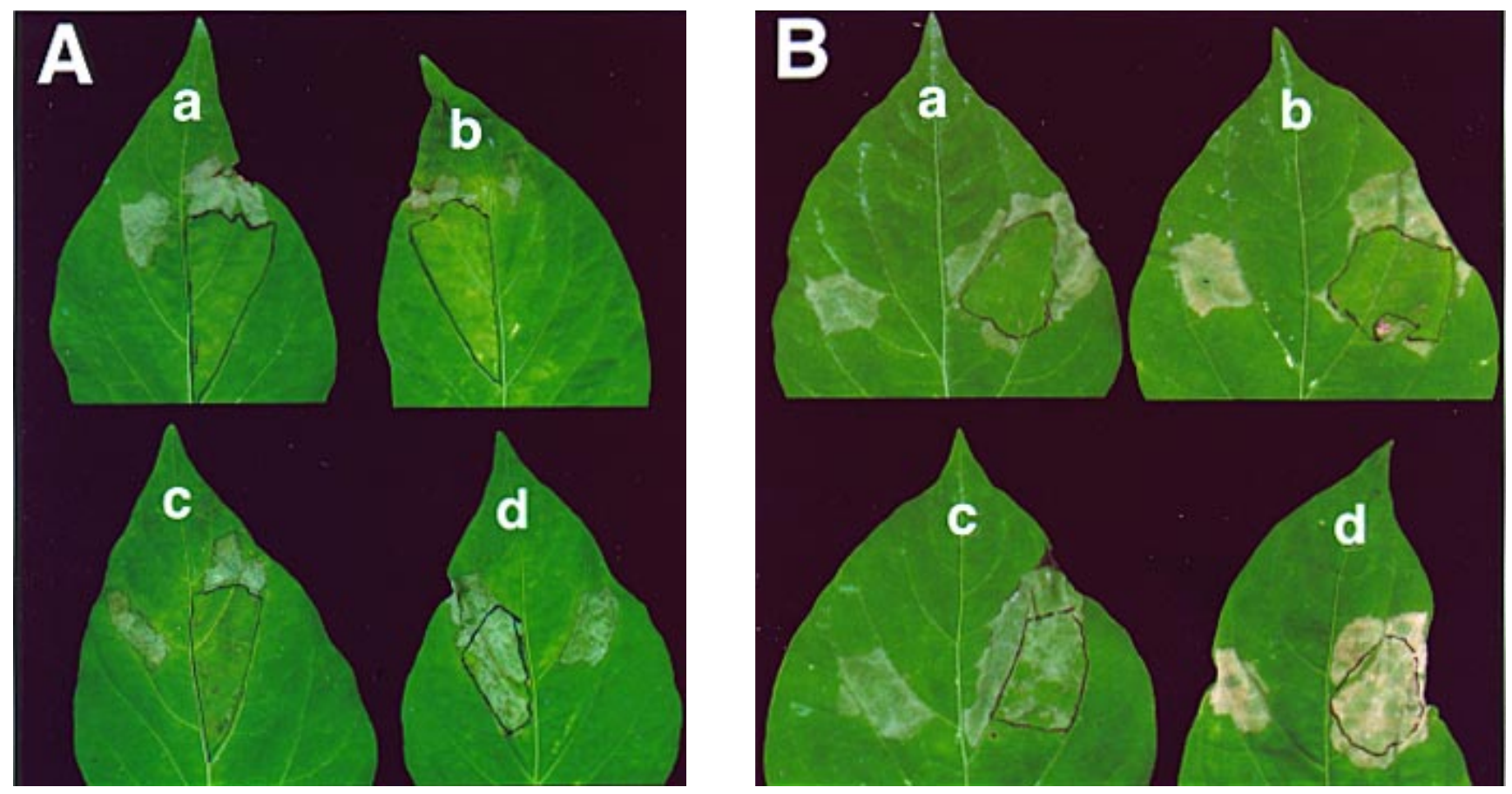

Fig. 1. Effects of inoculation of pepper ECW10R with lipopolysaccharides (LPS) or LPS derivatives from Xanthomonas campestris pv. campestris $(\mathrm{Xcc})$ or from rough mutants of Salmonella minnesota $(\mathrm{Sm})$ on the development of the hypersensitive response (HR). A pepper leaf area was inoculated with LPS or LPS derivatives and marked; $18 \mathrm{~h}$ later, $X$. campestris pv. campestris $\left(10^{7} \mathrm{CFU} \mathrm{ml} l^{-1}\right)$ was inoculated into the marked area, the immediately adjoining area, and in a panel on the other side of the midrib of the leaf (control). A, (a) water-phase LPS from Xcc at $50 \mu \mathrm{g} \mathrm{ml} \mathrm{l}^{-1}$; (b) phenol-phase LPS from $X c c$ at $50 \mu \mathrm{g} \mathrm{ml}^{-1}$; (c) core oligosaccharide of Xcc LPS at $5 \mu \mathrm{g} \mathrm{ml}{ }^{-1}$; (d) lipid A from Xcc at $50 \mu \mathrm{g} \mathrm{ml}^{-1}$. The phenol-phase LPS, which carries the Oantigen, water-phase LPS (which has no O-antigen), and the core oligosaccharide could prevent the HR response but lipid A was not active. B, (a) LPS from $S m$ Rc mutant at $50 \mu \mathrm{g} \mathrm{ml}^{-1}$; (b) LPS from $S m \mathrm{Rd}^{-1}$ utant at $50 \mu \mathrm{g} \mathrm{ml}{ }^{-1}$; (c) LPS from $S m$ Re mutant at $50 \mu \mathrm{g} \mathrm{ml}{ }^{-1}$; (d) lipid A from $S m \mathrm{Ra}^{2}$ mutant at $50 \mu \mathrm{g} \mathrm{ml}^{-1}$. LPS from the Re mutant, which contains lipid A attached to $(\mathrm{KDO})_{2}$, partially prevents HR whereas lipid A is inactive. 
tally ineffective at inducing LIR (data not shown). These results suggest that LIR induction in pepper by enteric bacterial LPS minimally requires the lipid A-KDO-KDO structure.

These results with enteric bacterial LPS are entirely consistent with the previous contention by Graham et al. (1977) that the active portion of the LPS molecule for induction of LIR is the intact lipid A-inner core oligosaccharide. However, in contrast to these previous observations, we have shown that the core oligosaccharide of LPS of $X$. campestris was effective in inducing LIR, an effect not seen with the core oligosaccharides of either $R$. solanacearum or the enteric bacteria. The differences in monosaccharide composition between these various oligosaccharides (Ojanen et al. 1993; Drigues et al. 1985) suggest substantial differences in the structure that may account for these observations. It is also possible that the oligosaccharide domain within LPS from other bacteria has LIRinducing activity but that the activity depends upon an acidlabile moiety that is lost as a consequence of the procedures used to derive the core oligosaccharide. This finding does not necessarily mean that the core oligosaccharide is the only structure in Xanthomonas LPS capable of inducing LIR. A lipid A-disaccharide core derivative (such as the LPS from the $S$. minnesota Re mutant) could also be active, although the lack of an appropriate LPS mutant in Xanthomonas means that we are not able to test this directly. However, the results show that the ability to induce LIR is not restricted to lipid A derivatives and can reside in different domains within LPS. As it is likely that the structure of the core oligosaccharide of Xanthomonas LPS differs significantly from that of the lipid A$\mathrm{KDO}_{2}$ of the enteric bacteria (Ojanen et al. 1993; Dow et al. 1995), we infer the existence of multiple pathways for LIR induction in pepper.

\section{ACKNOWLEDGMENTS}

The Sainsbury Laboratory is supported by a grant from the Gatsby Charitable Foundation. This work was carried out according to the pro- visions of the Ministry of Agriculture, Fisheries and Food license PHF1185/8(48) issued under the Plant Health (Great Britain) Order 1987 (statutory instrument 1758).

\section{LITERATURE CITED}

Bonas, U., Stall, R. E., and Staskawicz, B. 1989. Genetic and structural characterisation of the avirulence gene avrBs3 from Xanthomonas campestris pv. vesicatoria. Mol. Gen. Genet. 218:127-136.

Carlson, R. W., Kalembasa, S., Turowski, D., Pachori, P., and Noel, K. D. J. 1987. Characterization of the lipopolysaccharide from a mutant of Rhizobium phaseoli which is defective in infection thread development. J. Bacteriol. 169:4923-4938.

Daniels, M. J., Barber, C. E., Turner, P. C., Cleasy, W. G., and Sawczyc, M. K. 1984. Isolation of mutants of Xanthomonas campestris pv. campestris showing altered pathogenicity. J. Gen. Microbiol. 130: 2447-2455.

Dow, J. M., Osbourn, A. E., Wilson, T. J. G., and Daniels, M. J. 1995. A locus determining pathogenicity of Xanthomonas campestris is involved in lipopolysaccharide biosynthesis. Mol. Plant-Microbe Interact. 8:768-777.

Drigues, P., Demerylafforgue, D., Trigalet, A., Dupin, P., Samain, D., and Asselineau, J. 1985. Comparative studies of lipopolysaccharide and exopolysaccharide from a virulent strain of Pseudomonas solanacearum and from three avirulent mutants. J. Bacteriol. 162:504-509.

Graham, T. L., Sequeira, L., and Huang, T.-S. R. 1977. Bacterial lipopolysaccharides as inducers of disease resistance in tobacco. Appl. Environ. Microbiol. 48:424-432.

Matsuura, M., Kojima, Y., Homma, J. Y., Kubota, Y., Shibukawa, N., Shibata, M., Inage, M., Kusumota, S., and Shiba, T. E. J. 1983. Interferon-inducing, pyrogenic and proclotting enzyme of horseshoe crab activation activities of chemically synthesized lipid A analogues. Eur. J. Biochem. 17:639-642.

Mazzucchi, U., Bazzi, C., and Pupillo, P. 1979. The inhibition of susceptible and hypersensitive reactions by protein-lipopolysaccharide complexes from phytopathogenic pseudomonads: Relationship to polysaccharide antigenic determinants. Physiol. Plant Pathol. 14:1930

Ojanen, T., Helander, I. M., Haahtela, K., Korhoene, T. K., and Laakso, T. 1993. Outer membrane proteins and lipopolysaccharides in pathovars of Xanthomonas campestris. Appl. Environ. Microbiol. 59:41434151.

Sequeira, L. 1983. Mechanisms of induced resistance in plants. Annu. Rev. Microbiol. 37:51-79. 